\title{
The Microbiologically Influenced Corrosion of L245NS Carbon Steel by Sulfate-Reducing Bacteria in $\mathrm{H}_{2} \mathrm{~S}$ Solutions
}

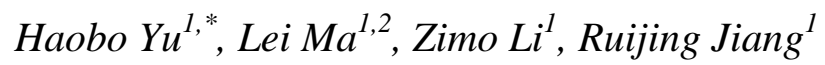 \\ ${ }^{1}$ Department of Materials Science and Engineering and Beijing Key Laboratory of Failure, Corrosion \\ and Protection of Oil/Gas Facilities, China University of Petroleum (Beijing), Changping District, \\ Fuxue Road 18, Beijing 102249, P. R. China \\ ${ }^{2}$ Research Institute of Oil and Gas Engineering, PetroChina Tarim Oilfield Company, Korla 841000, \\ P. R. China \\ *E-mail: $\underline{\text { Yu_h_b@sina.com }}$
}

doi: $10.20964 / 2018.10 .46$

Received: 5 June 2018 / Accepted: 23 July 2018 / Published: 1 September 2018

\begin{abstract}
The influence of sulfate-reducing bacteria (SRB) on the corrosion of L245NS carbon steel was investigated in a medium containing $\mathrm{H}_{2} \mathrm{~S}$ by various surface characterizations and electrochemical measurements. The addition of $\mathrm{H}_{2} \mathrm{~S}$ will totally inhibit the planktonic SRB in the medium. However, the sessile SRB in the corrosion crust can survive under the protection of the biofilm. Pitting corrosion is found under the corrosion crust, which is caused by the sessile SRB. The pitting corrosion rate is 1.1 $\mathrm{mm} / \mathrm{a}$. Additionally, the corrosion rate increases with the corrosion time. The SRB influenced corrosion mechanism of the steel is discussed.
\end{abstract}

Keywords: Carbon steel, Sulfate-reducing bacteria, Hydrogen sulfide, Microbiological corrosion, Pitting corrosion

\section{$\underline{\text { FULL TEXT }}$}

(C) 2018 The Authors. Published by ESG (www.electrochemsci.org). This article is an open access article distributed under the terms and conditions of the Creative Commons Attribution license (http://creativecommons.org/licenses/by/4.0/). 